\title{
INFLATION AND DEVALUATION EFFECTS ON FINANCIAL STATEMENTS: THE CASE OF TURKEY IN 2018
}

\section{Cenap Ilter*}

\begin{abstract}
Turkey has had another year of high inflation and high devaluation in its economic history. This has had negative consequences on growth and the future prospects of the country. This paper analyses the consequences of high inflation and the devaluation rates on financial statements. Inflation and devaluation create difficulties for both local companies and foreign subsidiaries in terms of financial reporting. A model company's transactions have been used to show the effects of inflation and devaluation on financial statements. The application of different IAS based reporting methods will create discrepancies for companies and especially foreign subsidiaries will be the ones most affected. Those who apply IAS 29 will have less loss and pay local taxes compared to companies who apply IAS 21 based reporting where no taxes are paid due to the considerable amount of losses. On the other hand, local companies not applying any of these rules will pay the highest amount of taxes, since the government did not request the restatement of financials based on IAS 29. The unclear rules create discrepancies on financial reporting and unbalanced competition. This paper purports that IAS 29 application will lead the financial statements to be presented fairly both for local and foreign subsidiaries in Turkey for the year of 2018.
\end{abstract}

Keywords: inflation, devaluation, financial reporting, tax reporting

JEL Classification: M41

\section{Introduction}

Inflation has been an ongoing problem for Turkey for many years with the trade deficit being the main cause of the problem. The currency (Turkish Lira - TL) has been devalued against all hard currencies as a consequence of its long sustained foreign deficit. Even though there have been two downturns in 2010 and 2012, inflation has been increasing for the last ten years in Turkey culminating in 20.3\% in 2018 (see Table 1). Likewise, the currency (TL) devaluation against the USD and the Euro has been high over the last ten years even though there have been two upturns in 2009 and 2012 and 2010 and 2012 for the USD and Euro respectively, culminating in $40.01 \%$ and $33.81 \%$ against the USD and Euro respectively in 2018 (see Table 2).

Table 1 | 2009-2018 inflation statistics

\begin{tabular}{|c|c|c|c|c|c|c|c|c|c|c|}
\hline \multicolumn{11}{|c|}{ TURKEY'S ANNUAL CONSUMER PRICE INDEX } \\
\hline 31-Dec-08 & 31-Dec-09 & 31-Dec-10 & 31-Dec-11 & 31-Dec-12 & 31-Dec-13 & 31-Dec-14 & 31-Dec-15 & 31-Dec-16 & 31-Dec-17 & 31-Dec-18 \\
\hline 160.44 & 170.91 & 181.85 & 200.85 & 213.23 & 229.01 & 247.72 & 269.54 & 292.54 & 327.41 & 393.88 \\
\hline$\%$ CHANGE & 6.53 & 6.40 & 10.45 & 6.16 & 7.40 & 8.17 & 8.81 & 8.53 & 11.92 & 20.30 \\
\hline
\end{tabular}

Source: Central Bank of Turkey (http://www.tcmb.gov.tr/wps/wcm/connect/en/tcmb+en)

* California State University Dominguez Hills, College of Business Administration and Public Policy (Cilter@csudh.edu). 
Table 2 | 2009-2018 devaluation statistics

\begin{tabular}{|c|c|c|c|c|c|c|c|c|c|c|}
\hline \multicolumn{11}{|c|}{ TURKISH LIRA'S ANNUAL DEVALUATION AGAINST DOLLAR } \\
\hline 31-Dec-08 & 31-Dec-09 & 31-Dec-10 & 31-Dec-11 & 31-Dec-12 & 31-Dec-13 & 31-Dec-14 & 31-Dec-15 & 31-Dec-16 & 31-Dec-17 & 31-Dec-18 \\
\hline 1.5218 & 1.4873 & 1.5376 & 1.8889 & 1.7776 & 2.1304 & 2.3269 & 2.9181 & 3.5192 & 3.7719 & 5.2810 \\
\hline$\%$ CHANGE & -2.27 & 3.38 & 22.85 & -5.89 & 19.85 & 9.22 & 25.41 & 20.60 & 7.18 & 40.01 \\
\hline \multicolumn{11}{|c|}{ TURKISH LIRA'S ANNUAL DEVALUATION AGAINST EURO } \\
\hline 31-Dec-08 & 31-Dec-09 & 31-Dec-10 & 31-Dec-11 & 31-Dec-12 & 31-Dec-13 & 31-Dec-14 & 31-Dec-15 & 31-Dec-16 & 31-Dec-17 & 31-Dec-18 \\
\hline 2.1332 & 2.1427 & 2.0551 & 2.4438 & 2.3452 & 2.9344 & 2.8272 & 3.1838 & 3.7099 & 4.5155 & 6.0422 \\
\hline$\%$ CHANGE & 0.45 & -4.09 & 18.91 & -4.03 & 25.12 & -3.65 & 12.61 & 16.52 & 21.71 & 33.81 \\
\hline
\end{tabular}

Source: Central Bank of Turkey (http://www.tcmb.gov.tr/wps/wcm/connect/en/tcmb+en)

Other hard currency devaluations have not been considered as the Eurozone is a major foreign trading partner of Turkey with $70-75 \%$ of its total foreign trade volume of approximately $\$ 400$ billion realized with the European Union and the rest mainly held in USD. The main cause of its economic problems is the foreign trade deficit (see Table 3). The chronic nature of the issue puts more pressure on interest rates in order to attract foreign investment and foreign borrowing to close the gap. In addition, the existence of a current account deficit pressurizes the country's foreign exchange reserves, which then leads to the devaluation of its currency.

\section{Table 3 | Turkey's foreign trade deficit}

\begin{tabular}{|c|c|c|c|c|c|c|c|c|c|}
\hline \multicolumn{7}{|c|}{ TURKEY'S CURRENT ACCOUNT (TRADE AND SERVICES) DEFICIT IN MILLION USD } \\
\hline 31-Dec-08 & $31-$ Dec-09 & $31-D e c-10$ & 31 -Dec-11 & 31 -Dec-12 & 31 -Dec-13 & $31-$ Dec-14 & 31 -Dec-15 & 31 -Dec-16 & 31 -Dec-17 \\
\hline$-39,425$ & $-11,358$ & $-44,616$ & $-74,402$ & $-47,963$ & $-63,642$ & $-43,644$ & $-32,109$ & $-33,137$ & $-47,357$ \\
\hline
\end{tabular}

Source: Central Bank of Turkey (http://www.tcmb.gov.tr/wps/wcm/connect/en/tcmb+en)

Inflation has always been an international problem. In the past, Brazil had a high inflation problem and helping the country break out of that debilitating cycle is the primary accomplishment of President Fernando Henrique Cardoso. He laid the foundations for today's outstanding performance as finance minister in 1994, bringing inflation down from 1,100\% in 1994 to $14.8 \%$ within a year (McCrary, 2001). Not only Brazil but Latin America as a whole has suffered from high inflation in the past decades. Surging inflation further eroded real tax revenues and exacerbated budget shortfalls, with governments often responding by printing more money. Latin American hyperinflation soared thousands of percentage points higher annually, rupturing economic activity and popular incomes in a way that has been unparalleled by any business cycle fluctuations since that time (Kaplan, 2018). Inflation reached 417,823\% in March (2008), as Zimbabweans returned to the harmonised presidential, senate, and parliamentary polls (Coomer and Gstraunthaler, 2011). All these findings imply that devaluation of currency seems to be an effective policy to make Bangladeshi products competitive in the world market (i.e., growth in exports) in the long term (Aziz, 2012). On the other hand, devaluation theoretically helps to reduce the current account deficit although this might 
not hold true in all circumstances, especially when the country is bound to primarily export one product - petroleum. Therefore, the study concludes that the official devaluation of the Nigerian currency does not have any significant impact on the trade balance for the period under review (Oluwoje and Ayodeji, 2019). Like Nigeria, South Africa is another example of high devaluation that is negatively affecting companies. Using sample data, we first demonstrate the unequivocal effect of inflation; i.e., higher inflation is necessarily harmful to all positive-growth firms (N'Cho-Oguie et al., 2011). For example, if an Argentinian operation had an immediate parent with the US dollar as its reporting currency, the Argentinian operation would report its operations using the US dollar (Ernst and Young, 2019). The following table shows the inflation and devaluation statistics of various countries for 2018 .

Table 4 depicts the countries (except Turkey) whose inflation rates exceeded 10\% for 2018 and their corresponding devaluations for the same period. The commonality of these countries is that they are either underdeveloped or a developing type of country and some of them are war ridden. Turkey (with 20.3\% inflation and $40 \%$ devaluation against the USD in 2018), as a developing country shares the same economic faith as these countries.

Table 4 | Comparison of high inflation and devaluation countries in 2018

\begin{tabular}{|l|c|c|c|c|}
\hline \multirow{2}{*}{ Country } & 2018 Inflation Rates \% (*) & \multicolumn{3}{|c|}{ Exchange Rates Against USD (**) } \\
\cline { 2 - 5 } & Consumer Price Index (CPI) & $\mathbf{1 2 / 3 1 / 2 0 1 7}$ & $\mathbf{1 2 / 1 3 / 2 0 1 8}$ & Devalaution \% \\
\hline Argentina & 34.3 & 19.16 & 37.65 & 96.50 \\
\hline $\begin{array}{l}\text { Democratic } \\
\text { Republic of Congo }\end{array}$ & 29.3 & $1,580.00$ & $1,630.00$ & 3.16 \\
\hline Egypt & 20.9 & 17.73 & 17.89 & 0.90 \\
\hline Ethiopia & 13.8 & 27.20 & 28.04 & 3.09 \\
\hline Iran & 31.2 & $36,057.00$ & $41,995.45$ & 16.47 \\
\hline Liberia & 23.4 & 125.17 & 156.71 & 25.20 \\
\hline Libya & 23.1 & 1.357 & 1.39 & 2.14 \\
\hline Sierra Leone & 16.9 & $7,645.00$ & $8,620.00$ & 12.75 \\
\hline $\begin{array}{l}\text { Republic } \\
\text { of South Sudan }\end{array}$ & 83.5 & 126.00 & 153.70 & 21.98 \\
\hline Sudan & 63.3 & 9.00 & 47.00 & 422.22 \\
\hline Ukraine & 10.9 & 28.145 & 27.70 & -1.58 \\
\hline Uzbekistan & 17.9 & $8,030.00$ & $8,310.00$ & 3.49 \\
\hline Yemen & 41.8 & 250.50 & 480.00 & 91.62 \\
\hline Zimbabwe & 10.6 & $(* * *$ & $(* * *$ & - \\
\hline
\end{tabular}

Source: Author's own processing

Note: $\left(^{*}\right) 2018$ rates source: https://www.imf.org/external/datamapper/PCPIPCH@WEO/WEOWORLD/VEN; ${ }^{(* *)} 2018$ rates source: https://www.fiscal.treasury.gov; $\left(^{* * *}\right)$ No reliable data. 
This paper analyses the consequences of high inflation and the devaluation rates on financial statements. It aims to find an answer to whether a local currency accounting method or application of International Accounting Standards-IAS 21 - The Effects of Changes in Foreign Exchange Rates method of accounting or application of IAS 29 - Financial Reporting in Hyperinflationary Economies method shows the true financial position of the company at the end of the inflationary and currency devaluation year of 2018.

\section{Literature review}

Inflation has had a devastating factor on many economies in the past and is still creating problems in the present. Gheorghe Suciu (2011) presented a recent development in Romania in his paper: he stated that even though Romania had a hyper-inflationist economy for more than 10 years, and current inflation is above the average of the European countries, the country did not have an applicable inflation accounting. If this had been done, the financial indicators would have also been re-evaluated. Authors in Turkey studied the inflation effects on financial statements through ratio analysis. The results yield valuable findings concerning the financial analysis of companies operating in hyperinflationary economy. The analysts to analyse companies in high inflation economy, even if not in hyperinflation, should evaluate ratios according to the findings of this article. (Karapinar, Zaif and Bayirli, 2012). Turkey has adopted inflation accounting adjustments in the past. The year 2003 was a turning point for inflation accounting in Turkey with inflation adjustments made on financial statements and as a consequence, understandable and comparable financial information was presented in these statements (Arsoy and Gucenme, 2008). The monetary unit assumption of financial accounting assumes a stable currency (i.e., constant purchasing power over time). Yet, even during periods of low inflation or deflation, nominal financial statements violate this assumption. I posit that, while the effects of inflation are not recognised in nominal statements, such effects may have economic consequences. I find that unrecognised inflation gains and losses help predict future cash flows as these gains and losses turn into cash flows (Konchitchki. 2011). Usage of hard currency such as the US dollar in inflationary economies is a common practice as the local currency loses its store of value. The literature has generally found that the demand for a secondary currency is tied primarily (though not exclusively) to store-of-value uses in developing economies and to medium-of-exchange uses in developed economies (Hellerstein and Ryan, 2011). People all over the world are aware of the effect of devaluations. This scenario shows that with a devaluation larger than the inflation, almost every group of households benefit. This is because most of the savings are in US dollars, while most of the debts are in Uruguayan pesos or indexed currency (Lluberas and Odriozola, 2015).

As explained in the introduction, economic turmoil might lead to sudden depreciation of the local currency. Typically, multiple rate systems emerge after a major shock hits the economy that exerts substantial pressure on the foreign exchange market and calls for a major depreciation of the equilibrium real exchange rate (De La Torre and Ize, 2013). One of their conclusions is that the path of the profit rate measured at current prices is not affected by the inflation rate. The profit rate at current prices allows for accurate measurement of the profit rate in the context of high inflation, functioning as the central variable in understanding the dynamics of capitalism in the Brazilian economy 
(Adalmir et al., 2019). Even though IAS 29 requires adjustments in hyperinflationary periods, there are critics of this rule. The greatest deterrent to adopting price level changes accounting is what it is not - inflation accounting is net present value, net realisable value, or current market values or fair value and therein lies much of the opposition to its use (Tawiah, Benjamin and Dorothee, 2015). However, International Financial Reporting Standards (IFRS) 13-Fair Value Measurement allows fair value on financial reporting and IAS 29 also requires that the restated amount of the non-monetary assets should not exceed its recoverable value. If this is the case, then the asset will be written down to its recoverable value. IFRS does not want any asset overstated but on the other side, a fair value concept linked to active market pricing, which is hard to find in the real world since many of fixed assets are custom made to the requirements of the manufacturing process, i.e. custom made power generators, machinery, physical plants. Besides, the fair value determination of such assets has an attached valuation cost. The frequency of independent valuations and the attached costs would be a concern plus the reliability of valuations might be another as one valuation by one party may differ from the other. Ernst and Young (2019) explains that the impracticability exception to the fair value requirement focuses primarily on whether a reporting entity would incur excessive cost if had to estimate fair value. According to them, this is a dynamic concept and, as such, the determination of what is excessive may differ from one reporting entity to another. In many instances, guidance that allows this type of exception defers the fair value measurement requirement until the level of uncertainty in such a measurement is reduced to an acceptable level. Inflation in Argentina has been very high for several years according to consensus observations, even though local inflation data has not been reported consistently by the public authorities. After declining for several months in 2017, inflation has increased significantly since early 2018 and the three-year cumulative inflation rate now exceeds $100 \%$ (PWC, 2018). In another research to investigate the inflation disclosure on improving the information content of the financial reporting of the accepted companies in the Tehran stock exchange market, the authors state that this issue leads to decreasing the revenues of the shares in an interval in which the inflation is high, and increasing them when the inflation is low. In fact, in spite of undeniable effects this phenomenon can have on the efficiency of the content of the financial reporting of the companies, the obtained result does not confirm such an issue (Khodadadi, Vaez and Alisufi, 2014). IAS 29 might not be the perfect solution, but it is the best alternative to a historical cost concept in the existence of hyperinflation. This paper will enhance the literature in this field as the extant literature does not take into account the comparative effects of inflation and devaluation on a single paper and on a single simulation model.

\section{Methodology}

An imaginary merchandising company established in Turkey on January 1, 2018, with TL100,000 paid-up capital $(\$ 26,512)$. It has 10 transactions (including a computer purchase) throughout the year. All transactions are recorded at TL. Each transaction is assumed to have occurred at the end of the month throughout the year. Adjustment entries (cost of goods sold, depreciation) are calculated and entries made at the end of the year (December 31, 2018). Local and deferred tax rate assumed to be $25 \%$. All transactions treated with three accounting methods: 
Local accounting method: Transaction recorded as explained above, then all balance sheet items (assets, liabilities and shareholders' equity) converted to USD at the closing rate (December 31, 2018). No local deferred tax figure calculated as no temporary differences appeared on non-monetary items (namely, inventory, fixed asset and accumulated depreciation).

IAS 21 - The Effects of Changes in the Foreign Exchange Rates method: All TL (which is the functional currency of a Turkish company operating in Turkey) transactions converted to USD (presentation currency) at the time of the event (end of the month, temporal method). All monetary items (cash, receivables, payables) converted to USD at closing rates and monetary gains and losses included in the income statement. In addition, a deferred tax liability (and expense) calculated at year-end since temporary differences appeared on non-monetary items. Deferred tax asset due to loss ignored in calculations. In this example, the assumption is that the local company is a foreign subsidiary of a US parent or any other multinational parent reporting in USD that requests its subsidiary to translate its functional TL figures to USD (presentation currency) based on the fact that there are non-local currency denominated transactions between the Turkish subsidiary and its parents and sisters in the same group. Besides, being specific to Turkey and its local regulations, foreign subsidiaries with a minimum paid-up capital of $\$ 100$ million are allowed to use reporting currency as their functional currency and pay their taxes accordingly. Under ASC Topic 830, Foreign Currency Matters, foreign entities within an enterprise that operate in different economic and currency environments may prepare financial statements in their respective functional currency. These functional currency financial statements are then translated into the enterprise's reporting currency for consolidation purposes (KPMG, 2018).

IAS 29 - Financial Reporting in Hyperinflationary Economies method: All nonmonetary TL transactions carried (restated) to purchasing power of December 31, 2018. Monetary gains and losses calculated at year-end and included in the income statement. In addition, a deferred tax liability (and expense) calculated at year-end due to temporary differences appeared on non-monetary items. Then all balance sheet items converted to USD at the closing rate of the year. Deferred tax asset due to loss ignored in the calculations. In this example, the last three years accumulated inflation is not around $100 \%$, which does not require a restatement of the financials per IAS 29 at December 31, 2018. However, in order to show the effects of the inflation even at lower rates, IAS 29 rules have been used and the inflation-adjusted figures have been converted to USD at December 31, 2018 closing rates.

Three methods of accounting treatments became comparable at December 31, 2018, as all three balance sheet presentations are in USD. These are presented in the tables below for comparison.

Table 5 shows the local accounting applications without any inflation adjustment nor any IAS 21 temporal method of conversion. All TL figures have been converted to USD at December 31, 2018 USD/TL rate in order to compare three balance sheets on Tables 5, 6 and 7. Table 5 shows a net income of $\$ 2,391$ after paying $25 \%$ local tax. 
Table 5 | Local accounting rules based balance sheet

\begin{tabular}{|l|r|l|r|}
\hline \multicolumn{2}{|l|}{ LOCAL CURRENCY (TL) BALANCE SHEET AS AT DECEMBER 31, 2018 CONVERTED TO USD* } \\
\hline Current Assets & 22,611 & Current Liabilities & 4,756 \\
\hline Office Equipment & 3,787 & Paid up Capital & 18,936 \\
\hline Accumulated Depreciation & -316 & Net Income/(Loss) & 2,391 \\
\hline Office Equipment-net & 3,472 & Total Shareholders' Equity & 21,326 \\
\hline Total Assets & 26,083 & Total Liabilities \& Shareholders' Equity & 26,083 \\
\hline * All figures have been converted to USD at December 31, 2018 currency rate. & \\
\hline
\end{tabular}

Source: Author's own data, as a result of 10 transactions occurred in 2018.

Table 6 shows the IAS 21 application of the temporal/historical method where all transactions have been converted into USD at the time of the occurrence of the economic event and then monetary gains and losses have been incorporated into the income statement comparing historical rates with December 31, 2108 rate on monetary items. In accordance with IAS 21 , the company has a loss of $\$ 3,640$, with the calculation of deferred tax due to temporary differences on non-current assets and accumulated depreciation, the total loss rises up to $\$ 5,680$.

Table 6 | IAS 21 based balance sheet

\begin{tabular}{|l|r|l|r|}
\hline \multicolumn{2}{|l|}{ IAS 21 BASED BALANCE SHEET AS AT DECEMBER 31, 2018 IN USD** } & 6,796 \\
\hline Current Assets & 22,803 & Current Liabilities & 26,512 \\
\hline Office Equipment & 5,264 & Paid up Capital & $-5,680$ \\
\hline Accumulated Depreciation & -439 & Net Income/(Loss) & 20,832 \\
\hline Office Equipment-net & 4,825 & Total Shareholders' Equity & 27,628 \\
\hline Total Assets & 27,628 & Total Liabilities \& Shareholders' Equity & 2 \\
\hline \multirow{2}{*}{$\begin{array}{l}\text { ** All transactions have been converted to USD at the date of the transaction and foreign exchange } \\
\text { gains and loses have been calculated at December 31, 2018 exchange rate. }\end{array}$}
\end{tabular}

Source: Author's own data, as a result of 10 transactions occurred in 2018.

Table 7 shows the IAS 29 application of inflation accounting where all non-monetary transactions have been carried into December 31, 2018 consumer price index (CPI) purchasing power. Then the monetary gains and losses incorporated into the income statement at December 31, 2018, and all TL figures have been converted to USD at the December 31, 2018 closing rate. In accordance with IAS 29, the company has a net profit of $\$ 55$ after paying local tax of $25 \%$. However, due to temporary differences on nonmonetary items, after the deferred tax liability deduction, the company has a loss of \$128. 
Table 7 | IAS 29 based balance sheet

\begin{tabular}{|l|r|l|r|}
\hline \multicolumn{2}{|l|}{ IAS 29 BASED BALANCE SHEET AS AT DECEMBER 31, 2018 CONVERTED TO USD*** } \\
\hline Current Assets & 22,708 & Current Liabilities & 4,160 \\
\hline Office Equipment & 4,477 & Paid up Capital & 22,780 \\
\hline Accumulated Depreciation & -373 & Net Income/(Loss) & -128 \\
\hline Office Equipment-net & 4,104 & Total Shareholders' Equity & 22,652 \\
\hline Total Assets & 26,812 & Total Liabilities \& Shareholders' Equity & 26,812 \\
\hline
\end{tabular}

** All non-monetary transactions have been restated to the year end purchasing power based on Consumer Price Index from the date of the transaction and monetary gains and losses have been calculated as of December 31, 2018, then all year end restated local currency figures have been converted to USD at December 31, 2018 closing rate.

Source: Author's own data, as a result of 10 transactions occurred in 2018.

Inflation is a consequence of supply and demand in every commodity/service including foreign exchange. The following example further explains the cause of the difference between the IAS 21 and IAS 29 results. For reporting purposes, a US subsidiary in Turkey starts a business with a shareholders' equity of TL 1,000 (\$500) at the beginning of the year when $\$ 1=$ TL 2. After a year of operations, the shareholders' equity rises to TL 1,500 ( $\$ 500)$ when $\$ 1=$ TL 3 whereas inflation has also been $50 \%$ in the same period. Then the company is no better or worse off after a year of business neither on the IAS 29 nor on the IAS 21 basis. However, if the currency rate at the end of the year is $\$ 1=$ TL 5, then the shareholders' equity ( $\$ 300$ ) is meant to have shrunk by $\$ 200$. However, this loss is for reporting purposes only (other comprehensive income for the parent) unless the company intends to withdraw its business from the country.

\section{Discussion (part 1)}

Restatement of financials is important in the sense that inflation is a monetary phenomenon and has an abrasive effect on purchasing power. The purchasing power of $100 \mathrm{TL}$ at December 31, 2017, is not equal to the purchasing power at December 31, 2018. With $20.3 \%$ inflation (in Turkey), it can only buy 83.12 TL worth of goods and services as at the 2018 year-end. Reflecting the effect of inflation on companies' financial statements is essential because it will affect not only the tax burden of the company but also the all income statement and non-monetary items on the balance sheet. Decisionmakers will be aware of the inflation effects on the company's financials and make their decisions accordingly. In the above case, the decision-maker (be it a potential or existing shareholder or a creditor) will know that when considering the abrasion effect of inflation on the financial statements, the company did not generate any profit and under normal circumstances would not be able to distribute any dividends. In addition, the same decision-maker will be able to compare the inflation-adjusted figures from the previous year(s) with the current year and be able to see the real progress or the deterioration of the company that they are interested in. The companies' plant, property, equipment, inventory, paid-up capital and retained earnings figures, all non-monetary assets, liabilities and shareholders' equity items will reflect the true purchasing power at the time 
of the reporting with appropriate depreciation charges in the income statement for the year of reporting. This type of reporting will enhance the vision of the decision-makers and lead them to make more informed decisions.

IAS 29 does not dictate a particular percentage and allows us to use our own judgement as to when it should be necessary to restate the financials. Its approach is three consecutive years of cumulative inflation percentage should approach or exceed $100 \%$. That means an average of $26 \%$ annual inflation for three consecutive years will require an inflation adjustment. However, the study in this paper concludes that inflation adjustment may be necessary even at lower rates (20.3\%). A lower than $26 \%$ inflation adjustment has completely opposite effects compared to local accounting records (local net income \$2,391 versus IAS 29 based of $-\$ 128)$.

Per the IAS 29 requirement for three consecutive years of inflation ending at December 31, 2018, inflation has been $46.13 \%$ in Turkey. This reflects that three years cumulative effect on the 2018 year-end financials would result in a loss of $\$ 4,071$, which is construed as the higher the inflation, the greater the loss, as long as the company's current assets exceed its current liabilities.

On the other side, the net income figure on IAS 21 based financials is $\$ 5,680$ for the year 2018. There are three different results on three different reporting basis and the specifics of Turkish Procedural Tax Law need to be looked into to understand the subject matter more clearly.

\section{Turkey's specific conditions}

According to the Procedural Tax Law (item 298) of Turkey, inflation adjustment is required if the last three years' inflation index exceeds $100 \%$ or the current year's index exceeds $10 \%$. Since 2018 annual inflation exceeded $10 \%$, it was possible that the government would mandate the companies to adjust their financials with the inflation index. However, inflation accounting works two ways: If current assets exceed current liabilities then the probable monetary losses will reduce the taxable income. On the other hand if current assets are less than current liabilities it will hike up monetary gains, which will lead the company to have more taxable income. Therefore, it was more of a political issue. Companies in the latter case put pressure on the government through their associations to not pay (additional) taxes while struggling with debts and paying interest. Although when considering this, it is worth noting that during Turkey's economic turmoil in 2018 the government did not apply the IAS 29 adjustments for reporting and tax purposes. Having said that, IAS 21 applications are still applicable if the foreign company made a certain level of investment in the country. According to Procedural Tax Law item 215, foreign companies' investments (subsidiaries) in Turkey that are not less than $\$ 100$ million can keep their accounts in another currency and can pay their taxes accordingly converted to TL at the time of the tax filing. Foreign companies, if adopting this accounting method, are not allowed to apply the inflation accounting applications. This is an incentive to attract foreign direct investment in Turkey.

\section{Discussion (part 2)}

Based on the model company above, it is assumed that there are two identical foreign subsidiaries and both have paid-up capital of $\$ 100$ million; one keeps its records based 
on IAS 21 and the other based on IAS 29. After incorporating Turkey's specific tax rules for IAS 21 and 29 applications. An IAS 21 based income company would end up with a high loss USD figure and would not pay any local taxes whereas an IAS 29 based company would end up with a lesser USD loss figure and pay a small amount of local taxes (\$18 per the simulation model). On the other hand, a local Turkish company with the same paid-up capital not applying any of these rules will end up with a net profit and paying a considerable amount of taxes ( $\$ 797$ per the simulation model). There are three results with three accounting methods. If the government had declared that for 2018, in general, companies would restate their financials in accordance with the inflation adjustment and paid their taxes accordingly then companies would apply IAS 29 and pay a lesser amount of taxes than if they did not adjust their financials with inflation. However, this would mean the government would collect less tax from companies for 2018. Considering the financial turmoil of the economy in 2018, the government could not afford it. Companies with a minimum of $\$ 100$ million paid-up capital would never pay any income/corporate taxes and would be in an advantageous position vis a vis the IAS 29 based companies. IAS 21 based companies are more cash-rich with the existing accounting-tax applications. In addition, they even book deferred tax assets if there is a prospect of future profits. Assuming that there are two foreign subsidiaries, one has IAS 21 based reporting while the other has IAS 29 based reporting, their reported income figures will be totally different for 2018. The reasons for this discrepancy are:

- IAS 29 does not mandate a specific rate to apply inflation adjustments.

- IAS 21 is always applicable no matter what the inflation is.

The local accounting method produces the highest profit and pays the highest taxes as is depicted in the model. From a business point of view, a business owner would want to sustain its business and expand if possible. In economically depressed periods, businesses are concerned about maintaining their capital. The simulation model shows that under inflationary pressures, the model company starts with a $\$ 26,512$ capital and ends up with $\$ 21,326$ a year after. This implies that the company produced fictitious profits and paid taxes to the government and shrunk in size in reality. In other words, inflation is a form of taxation from a government perspective. A company's options might be to continue its business or change its business line or terminate. If a company decides to continue with sustained inflation and devaluation in the country, it should find a way to conduct its local transactions in USD (or any other hard currency) that might help protect its initial paid-up capital. IAS 29 defines the indicators for the existence of hyperinflation of the country. The first two of the indicators are as follows (source: https:/www.iasplus.com/en/standards/ias/ias29):

- The general population prefers to keep its wealth in non-monetary assets or in a relatively stable foreign currency. Amounts of local currency held are immediately invested to maintain purchasing power.

- The general population regards monetary amounts not in terms of the local currency but in terms of a relatively stable foreign currency. Prices may be quoted in that currency. 
Turkey currently implements the two conditions above even though the three years' cumulative inflation is $46.13 \%$, i.e. 10 -year government bonds in 2019 are paying interest at $18-20 \%$ whereas 2018 inflation has been $20.3 \%$ and current inflation (CPI, April 2019) is $19.5 \%$. Government bonds do not pay any real interest and with companies and the public being aware of this, invest their money in foreign denominated bank accounts (from August 2018 of $\$ 79.1$ billion to $\$ 92.5$ billion in February 2019).

Even though the government numbers do not indicate it, public behaviour tells us that hyperinflation conditions exist in the economy. Due to its economic reality, Turkey is a dual currency country - TL and USD. It is an import prone country with a long endured foreign deficit problem and businessmen would indicate their prices in both USD and Euro to protect their financial position against the abrasive effects of the inflation and devaluation. The other option is to change their business line, i.e. from local currencybased transactions to foreign exchange based transactions with the possibility of exports although it requires training and additional knowledge of the new business. It has a cost but changing the course of business from domestic markets to international markets could be a solution.

In the case of a pessimistic scenario where the business liquidates itself then inflation-adjusted local currency and USD denominated financials might not show the economic reality of the company. The economic reality would be fair value. Fair value might approximate the inflation-adjusted or foreign-denominated currency values, but it is a possibility, not a fact. Based on the model company, in case of liquidation, a businessman who liquidates themselves at the end of December 2018, might end up with a $\$ 21,326$ or $\$ 20,832$ or $\$ 22,652$. All of these figures are lower than the initial capital of $\$ 26,512$. Theoretically, they are losing anyway but practically this may not hold true. The gain/loss will be determined with market forces at the time of liquidating the business assets, paying off liabilities and whatever remains in the business's vault at the end of the liquidation process. Having said that, the possibility of a scenario that the business will hold more cash than $\$ 26,512$ after liquidation in a shrinking economy is much less likely (Turkey - 2017 GDP \$851,491; 2018 GDP \$787,087). According to the Turkish Treasury (https://www.hmb.gov.tr/ekonomik-gostergeler), the Turkish economy shrank by $7.5 \%$ in 2018 on a USD basis.

Alternatively, management might try to reflect monetary losses to its suppliers by deferring payments. In a competitive market, this has limits because everybody is in the same ship and are all thinking of the same solutions in order to stay liquid. Financially strong companies may apply this method to a limited extent at the expense of smaller sized companies. The extent is limited because there are liabilities that by nature cannot be deferred, i.e. monthly employee income taxes, value-added taxes, salaries, bank interest and principal loan payments. Besides, deferring payments might be contagious in the markets, which would lead to illiquidity in all sectors.

In all possible scenarios, business owners in Turkey would measure their equity in inflation-adjusted local or hard currency-denominated figures and compare them with the current value of their inventories and net fixed assets. In other words, they would measure if they are maintaining their physical capital. Considering the risk factors of the business, if they observe that their physical capital value is in excess of the initial investment, they will continue and stay in business and if not, they will seek other solutions and liquidating the business cannot be ruled out. According to Bloomberg News 
(https://www.bloomberg.com/quote/GTRU10YR:IND), Turkish Eurobonds yield is 7.89\%, i.e. if government Eurobonds are paying a tax-exempt $7 \%$ interest and if they are hardly making 5\% net profit return on their equity, they might think of liquidating the business and get rid of all the risks and invest in riskless government bonds.

\section{Conclusion}

This is the reality of using more than one criterion when presenting the financials leading to the above discrepancies. This is a consequence of the high volatility of TL against the USD and other hard currencies throughout the year. According to the above scenario, the two companies' operations and financials are presenting two opposite results, and both are correctly reporting in accordance with Turkish Procedural Tax Law and IAS requirements. There are multiple reasons for devaluation and inflation that are not running in tandem. Interest rates, foreign exchange deficits, expectations of people and central bank interventions in the markets all have effects on inflation and devaluation. Of the two results above, the true position of the company is reflected through the IAS 29 accounting reporting method. Currency conversion is an indicator. As mentioned above, currencies are under the effect of various forces and might zig-zag due to the influence of these forces. Over the long term, inflation and devaluation catch each other but not in the short term. Therefore, restating the local-functional currency figures per IAS 29 is the best solution for both local and foreign companies in Turkey and anywhere else in the world where there is high inflation. Regarding foreign subsidiaries' presentation to the parent (for consolidation), these restated financials can be converted to USD or any other hard currency at the year-end closing rates.

\section{References}

Arsoy, P., \& Gucenme, U. (2008). The Development of Inflation Accounting in Turkey. Critical Perspectives on Accounting, 20(5), pp. 568-590. https://doi.org/10.1016/j.cpa.2008.01.006

Aziz, N. (2012). Does a Real Devaluation Improve the Balance of Trade? Empirics from Bangladesh Economy. The Journal of Developing Areas, 46(2), pp. 19-41. https://doi.org/10.1353/jda.2012.0033

Coomer, J., \& Gstraunthaler, T. (2011). The Hyperinflation in Zimbabwe. The Quarterly Journal of Austrian Economics, 14(3), pp. 311-346.

De La Torre, A., \& Ize, A. (2013). Exchange Rate Unification: The Cuban Case [online]. World Bank. Brookings Series. Available at: https://www.brookings.edu/wp-content/uploads/2016/06/Cubas-Economic-ChangeEnglish-web-1.pdf [Accessed 25 Sept. 2019]

Ernst and Young (2019). Financial Reporting Developments: Fair Value Measurement [online]. Available at: https://www.ey.com/publication/vwluassetsdld/ financialreportingdevelopments_bb1462_fairvaluemeasurement_25july2019/\$file/ financialreportingdevelopments_bb1462_fairvaluemeasurement_25july2019.pdf [Accessed 25 Sept. 2019]

Hellerstein, R., \& Ryan, W. (2011). Cash Dollars Abroad [online]. Federal Reserve Bank of New York. Staff Reports. Available at: https://www.newyorkfed.org/medialibrary/media/research/ staff_reports/sr400.pdf [Accessed 25 Sept. 2019]

Kaplan, S. B. (2018). Fighting Past Economic Wars: Crisis and Austerity in Latin America, Latin American Research Review, 53(1), pp. 19-37. https://doi.org/10.25222/larr.292 
Karapinar, A., Zaif, F., \& Bayirli, R. (2012). Impact of Inflation Accounting Application on Key Financial Ratios. Journal of Business Research - Türk, 4(1), pp. 44-57.

Khodadadi, V., Vaez, \& Alisifi, H. (2014). Investigating the Effect of Inflation Disclosure on Improving the Information Content of the Financial Reporting. International Journal of Financial Research, 5(3), pp. 96-109. https://doi.org/10.5430/ijfr.v5n3p96

Konchitchki, Y. (2011). Inflation and Nominal Financial Reporting: Implications for Performance and Stock. The Accounting Review, 86(3), pp.1045-1085.

https://doi.org/10.2308/accr.00000044

KPMG (2018). Foreign Currency Handbook. [online] kpmg.com. Available at: https://frv.kpmg.us/ content/dam/frv/en/pdfs/2018/foreign-currency-handbook.pdf [Accessed 25 Sept. 2019]

Lluberas, R., \& Odriozola, J. (2015). Inflation, Currency Depreciation and Households Balance Sheet in Uruguay [Working paper no. 2015009, online]. Banco Central del Uruguay, pp. 17-18, Available at: https://www.bcu.gub.uy/Estadisticas-e-Indicadores/Documentos\%20de\%20 Trabajo/9.2015.pdf [Accessed 25 Sept. 2019]

Marquetti, A., Morrone, H., Alessandro, M., \& Ourique, L. (2019). Measuring the Profit Rate in an Inflationary Context: The Case of Brazil, 1955-2008. Review of Radical Political Economics, 51(1), pp. 52-74. https://doi.org/10.1177/0486613416689834

McCrary, E. (2001). Brazil Is Hot Now What? Global Finance, 15(6), p. 31.

N'Cho-Oguie, C., Blakley, D., Murray, W., \& Smith, B. (2011). Econometric Analysis of Functional Relationship Between Inflation and Growth of Firms in South Africa: Empirical Research Findings. Journal of Financial Management \& Analysis, 24(2), p. 2.

Oluwoje, A., \& Ayodeji, A. (2019). Naira Devaluation and Trade Balance in Nigeria. World Scientific News, 125(April), pp. 181-192.

PWC (Price Waterhouse Coopers), (2018). Hyperinflation in Argentina: Which Implications for Your Consolidated Financial Statements? [online]. Available at: https://www.pwc.fr/fr/assets/files/pdf/2018/10/pwc-en-hyperinflation-in-argentinawhich-implications-for-your-consolidated-financial-statements-2.pdf [Accessed 25 Sept. 2019]

Suciu, G. (2011). Inflation Accounting at International Level [online]. Bulletin of the Transilvania. Available at: http://webbut.unitbv.ro/BU2011/Series\%20V/BULETIN\%20V\%20PDF/27\%20 suciu\%20g\%201\%20BUT\%202011.pdf [Accessed 25 Sept. 2019]

Tawiah, V., Benjamin, M., Konadu, B., \& Mukakibibi, D. (2015). Inflation Accounting: More Questions than Answers. International Journal of Management and Business, 5(3), pp. 150-164. https://doi.org/10.2139/ssrn.2592883

\section{Online Sources}

https://www.bloomberg.com/quote/GTRU10YR:IND

https://www.fiscal.treasury.gov

https://www.hmb.gov.tr/ekonomik-gostergeler

https://www.iasplus.com/en/standards/ias/ias29

https://www.imf.org/external/datamapper/PCPIPCH@WEO/WEOWORLD/VEN

http://www.tcmb.gov.tr/wps/wcm/connect/en/tcmb+en 